Discussion Paper No. 11-017

Effects of Age at School Entry (ASE) on the Development of Non-Cognitive Skills: Evidence from Psychometric Data

Andrea M. Mühlenweg, Dorothea Blomeyer, and Manfred Laucht

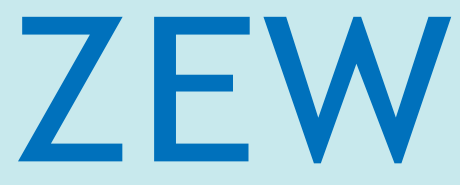

Zentrum für Europäische Wirtschaftsforschung $\mathrm{GmbH}$

Centre for European

Economic Research 
Discussion Paper No. 11-017

\title{
Effects of Age at School Entry (ASE) on the Development of Non-Cognitive Skills: Evidence from Psychometric Data
}

\author{
Andrea M. Mühlenweg, Dorothea Blomeyer, \\ and Manfred Laucht
}

Download this ZEW Discussion Paper from our ftp server:

ftp://ftp.zew.de/pub/zew-docs/dp/dp11017.pdf

Die Discussion Papers dienen einer möglichst schnellen Verbreitung von neueren Forschungsarbeiten des ZEW. Die Beiträge liegen in alleiniger Verantwortung der Autoren und stellen nicht notwendigerweise die Meinung des ZEW dar.

Discussion Papers are intended to make results of ZEW research promptly available to other economists in order to encourage discussion and suggestions for revisions. The authors are solely responsible for the contents which do not necessarily represent the opinion of the ZEW. 


\section{Das Wichtigste in Kürze}

In dieser Studie untersuchen wir, wie sich ein relativ junges oder älteres Einschulungsalter, das aus einem Geburtstag vor oder nach dem Stichtag für die Einschulung resultiert, auf die Entwicklung nicht-kognitiver Fähigkeiten der Kinder auswirkt. Wir identifizieren insbesondere Effekte des entsprechenden Alters bei der Einschulung (ASE) auf die Temperamentsentwicklung. Als Datengrundlage verwenden wir psychometrische Maße der Mannheimer Risikokinderstudie (MARS), einer Längsschnittstudie einer Geburtskohorte im Rhein-NeckarGebiet. Die Schätzergebnisse zeigen, dass sich Kinder, die relativ älter eingeschult wurden, in vielerlei Hinsicht vorteilhaft entwickeln: Bei diesen Kindern beobachten wir eine höhere Persistenz sowie seltener Hyperaktivität. Die Ergebnisse sind robust, wenn wir das Temperament der Kinder vor der Einschulung mit berücksichtigen. Wir zeigen zudem, dass der Effekt des Einschulungsalters auf die Persistenz über das Grundschulalter hinweg stabil bleibt, indem wir Kinder sowohl im Alter von acht als auch mit elf Jahren beobachten. Darüber hinaus besteht im Alter von elf Jahren ein messbarer Effekt auf die Anpassungsfähigkeit der Kinder. Insgesamt sind die Ergebnisse ein klarer Beleg für die Formbarkeit des Temperaments nach der Einschulung. Im Gegensatz zu den nicht-kognitiven Fähigkeiten konnten keine signifikanten Einflüsse des Einschulungsalters auf kognitive Fähigkeiten (Intelligenzquotient) beobachtet werden.

Ausgehend von unseren Ergebnissen wird sich Eltern von vor dem Einschulungsstichtag geborenen Kindern vermutlich die Frage stellen, ob es sinnvoll sein kann, Kinder, die regulär relativ jung eingeschult würden, für ein Jahr vom Schulbesuch zurückzustellen. Ein entsprechendes Kind würde dann bei seiner Einschulung zu den Ältesten in der Klasse gehören. Dies könnte dem Kind einen Vorteil verschaffen, der seine weitere Entwicklung begünstigt. Um nähere Aussagen zur Rückstellung treffen zu können, wurde gesondert eine Gruppe zurückgestellter Kinder untersucht. In dieser Gruppe von Kindern finden wir nicht bestätigt, dass sie von einer Rückstellung profitieren. Es ist jedoch wichtig zu beachten, dass diese Kinder eine selektive Stichprobe bilden, da die Rückstellung meist aufgrund von Entwicklungsproblemen vor der Einschulung erfolgt. Im Ergebnis halten wir fest, dass ein einfacher Altersvorteil noch keine Garantie für eine erfolgreiche Entwicklung ist. Um die generellen Nachteile der jung eingeschulten Kinder auszugleichen, erscheinen andere Maßnahmen erforderlich, die auf die Bedürfnisse der relativ Jüngsten in den Jahrgängen eingehen. 


\section{Non-Technical Summary}

In this paper, we examine how school enrollment at a relatively younger or older age in relation to age-based cut-off dates for school entry affects the development of non-cognitive skills. Specifically, we identify effects of age at school entry (ASE) on the development of child temperament. Our analysis is based on psychometric measures from the Mannheim Study of Children at Risk (MARS), a longitudinal cohort study of children in the RhineNeckar region in central Germany. In children with a higher ASE due to a birthday late in the year, we find more favorable outcomes with respect to several temperamental dimensions: These children are more persistent and less often hyperactive. The findings are robust if we control for the respective temperamental dimension before entering school. We also show that the ASE effect on persistence is stable over time also after leaving elementary school by comparing the children at age eight and age eleven, after the children have entered Germany's segregated secondary-school tracks. At age eleven, we additionally find significant ASE effects on adaptability to change. Overall, the results point to a high degree of malleability in the considered non-cognitive skills after school entrance. In contrast to non-cognitive skills, we could not find significant impacts of ASE on cognitive skills (IQ).

Based on our results, parents may wonder whether it is beneficial to retain children from entering school at a relatively young age. Retaining children for a year would make them the oldest within the class once they enter school. This could be an advantage that fosters their further development. In order to answer the question on retention, we have also examined the performance of children who are actually retained. At least in this group of students, we do not find that retention is beneficial. However, it has to be kept in mind that these children constitute a selected sample, since parents will more often retain children with some kind of developmental problems. We assume that the results provide some evidence that simply making children enter at an older age does not confer benefits. Other policy measures are needed in order to specifically assist children who are disadvantaged because of their relatively young age. 


\title{
Effects of Age at School Entry (ASE) on the Development of Non-Cognitive Skills: Evidence from Psychometric Data
}

\author{
Andrea M. Mühlenweg* \\ Dorothea Blomeyer ${ }^{\#}$ \\ Manfred Laucht ${ }^{\#}$ \\ * Centre for European Economic Research (ZEW), Mannheim, Germany \\ \# Central Institute of Mental Health (ZI), Mannheim, Germany
}

\author{
Corresponding Author: \\ Andrea M. Mühlenweg \\ Centre for European Economic Research (ZEW) \\ L7, 1 \\ 68161 Mannheim \\ Germany \\ Phone: +49 621-1235-280 \\ Phone: +49 621-1235-225 \\ E-mail:muehlenweg@zew.de
}

\begin{abstract}
We identify effects of age at school entry (ASE) on the development of child temperament. Our analysis is based on psychometric measures from a longitudinal cohort study of children in the Rhine-Neckar region in central Germany. In children with a higher ASE due to a birthday late in the year, we find more favorable outcomes with respect to several temperamental dimensions: These children are more persistent and less often hyperactive. The findings are robust if we control for the respective temperamental dimension before entering school. We also show that the ASE effect on persistence is stable over time by comparing the children at age eight and age eleven, after the children have entered Germany's segregated secondary-school tracks. At age eleven, we additionally find significant ASE effects on adaptability to change. Overall, the results point to a high degree of malleability in the considered non-cognitive skills after school entrance.
\end{abstract}

JEL classification: I21, I28, J24

Keywords: education, identification, instrumental variables, age at school entry (ASE)

Acknowledgment: We gratefully acknowledge support by the Leibniz Association within the project "Non-Cognitive Skills: Acquisition and Economic Consequences." Funding support from the German Research Foundation (DFG) is gratefully acknowledged for conducting the survey (MARS). We especially thank Katja Coneus for fruitful discussions and help in preparing the data for this paper. We are also grateful to Silke Anger, James Heckman, Melinda Morrill, Dave Ribar, Chris Ruhm, C. Katharina Spieß and seminar participants at ZEW, the London School of Economics, and the Department of Economics at the University of North Carolina at Greensboro for very valuable comments on earlier versions of this work. 


\section{Introduction}

Parents are interested in how educational institutions affect their child's development, for schooling may impact not only cognitive skills but also various dimensions of personal growth. In this paper, we examine how school enrollment at a relatively young age in relation to age-based cut-off dates for school entry affects the development of non-cognitive skills. Economists have observed that cognitive skills are especially malleable in early childhood, before children enter school, and that non-cognitive skills seem to be also malleable in the later childhood years (e.g. Cunha, Heckman, Lochner and Masterov, 2005). This paper provides evidence on the malleability of children’s non-cognitive skills after school entry. To assess non-cognitive skills, we draw on measurements of child temperament at age 4.5, 8 and 11. ${ }^{1}$ Psychologists consider child temperament to be an open system, developing over time in the context of experiences (cf. Rothbart and Bates, 1998). ${ }^{2}$ Therefore, one would expect that experiences made in school affect the development of temperamental traits. Additionally, we observe child IQ results as a measure of cognitive skills.

There is ample evidence in the existing literature that, at least in the short-run, a relatively younger age at school entry (ASE) negatively impacts child educational outcomes (e.g. Fredriksson and Öckert, 2005; Bedard and Dhuey, 2006; Mühlenweg and Puhani, 2010). Recent studies have also gone beyond examining traditional school outcomes like test scores and educational attainment: Dhuey and Lipscomb (2010), for example, provide evidence that relatively younger students in the US are more often classified as having learning disabilities than older students. Similarly, Elder and Lubotsky (2009) and Evans, Morrill and Parente (2010) report that relatively younger students are more often classified as having Attention Deficit Disorder (ADD) or Attention Deficit Hyperactivity Disorder (ADHD). Other recent

\footnotetext{
${ }^{1}$ Temperament is defined as constitutionally based (i.e. rooting on a biological basis of genetic inheritance, maturation and experience) individual differences in emotional, motor and attentional reactivity and selfregulation and includes differences in basic psychological processes constituting the affective, activational and attentional core of personality and its development (Rothbart \& Bates, 1998).

${ }^{2}$ This is true even if temperamental traits are to some extent stable over time and situations (cf. Buss and Plomin, 1975).
} 
studies have focused on social outcomes: Using data from 17 countries, Mühlenweg (2010) shows that relatively young students within a given grade are more often victims of school violence. Similarly, for the US, Dhuey and Lipscomb (2008) report that students who enter school at a relatively old age due to their birth dates are significantly more likely to hold a high school leadership position than relatively younger students. Based on Norwegian data, Black, Devereux and Salvanes (2008) show that younger school entrants have a higher probability of teenage pregnancy. We are not aware of previous studies observing ASE effects on the development of non-cognitive skills.

In this paper we draw on a unique panel database from the Rhine-Neckar region in central Germany that contains psychometric information on child temperament. We use children's assigned age at school entry (AASE) as an instrument to identify the age at school entry (ASE) effects, as this is the standard used in the above-mentioned empirical literature. Assigned age at school entry is solely determined by date of birth. The panel structure of the data also allows us to control for children's temperament prior to school entrance (at age 4.5), and thereby check the robustness of our results. We show that children entering school at a relatively young age because of school entry-age regulations are significantly less persistent but more often hyperactive when observed at age 8 . At age 11, the effect on activity is not significant. However, we find that at age 11, young school entrants are also significantly less adaptive to change. ASE exerts no significant impact on IQ, which is consistent with the view of a lower malleability of cognitive skills after early childhood. Our findings are robust if we control for the respective temperamental dimension prior to school entrance.

The paper proceeds as follows: Section 2 explains the identification strategy in order to estimate ASE effects. Section 3 details the database, its psychometric measures and presents summary statistics. Section 4 presents and discusses the results from the instrumental variable estimation and several robustness checks. Section 5 concludes. 


\section{Identification Strategy}

Causal analysis of the effects of ASE is hampered by the fact that a child's development prior to entering school might influence when enrollment occurs. If children with developmental problems tend to be held back to the following year, they will be the oldest in the class upon enrollment. As a result, if we found a negative correlation between higher age at school entry and the dimensions of child temperament, this would not allow us to conclude that ASE has negative effects on temperament. Such a negative correlation could rather imply that entering school later did not improve a child's initial problems; children who enroll later because of developmental problems may simply still have problems when observed later on. We are thus faced with a case of potential reverse causality. ASE might be endogenous to the outcomes of interest.

In order to identify the causal effects of age at school entry, in our main identification strategy we draw on the official ASE rule which was instituted in West Germany in the late 1980s. The rule states that children should enter school in the year they turn six if they are born between January and June. ${ }^{3}$ Those born between July and December should enter a year later. About $81 \%$ of children in our sample entered school according to the official rule. $10 \%$ entered school when they were a year older than the recommended age and $9 \%$ entered a year younger.

According to the ASE rule, a major source of variation in ASE is variation in birth date. Also, this part of the variation may be considered to be exogenous to the outcome variables. We use this exogenous source of variation in the ASE in order to identify causal effects. ${ }^{4}$ First, we regress each of the different dimensions of temperament on the assigned

\footnotetext{
${ }^{3}$ School officially begins in Germany with the first grade; unlike the US kindergarten (known in Germany as "Vorschule") is not considered the first year of school and is not mandatory.

${ }^{4}$ The instrument has previously been criticized, and may be invalid if 1) parents deliberately time births in order to make their children enter school at a specific age; or 2) if date of birth has a direct effect on the outcomes of interest. However, based on data from the U.S., Dickert-Conlin and Elder (2010) recently provided evidence against the deliberate timing of childbirth with respect to the cut-off date. Additionally, they show that the incidence of a birth date before a cut-off date is not related to mothers' characteristics and early child outcomes.
} 
ASE. ${ }^{5}$ A positive coefficient on some of the dimensions of temperament would indicate that entering school relatively old due to a birth date after the cut-off has a positive effect on temperament. Since this reduced-form estimation is calculated based on the sample of all children and not all children comply with the ASE rule, this effect may be considered a net effect of being born after the cut-off date. If everyone were forced to comply with the ASE rule, the effect of being born late in the year would potentially be higher.

In a second step, we use instrumental variable estimation in order to identify a causal effect of age at school entry. To this end, the recommended ASE is taken as an instrument for observed ASE. This means that we conduct a two-stage least square (2SLS) estimation with the following equations:

$$
\begin{aligned}
& A S E_{i}=\alpha_{1}+\beta_{1} * A A S E_{i}+\beta_{2} X_{i}+\varepsilon_{i} \\
& T_{k, i}=\alpha_{2}+\beta_{3}\left(A S E_{\text {predicted }, i}\right)+\beta_{4} X_{i}+\eta_{i},
\end{aligned}
$$

where $A A S E_{i}$ represents individuals’ assigned age at school entry (AASE) according to birth date and $X_{i}$ represents potential control variables to be included in the regressions. $T_{k, i}$ is the temperamental dimension $k$ of child $i$ and $A S E_{\text {predicted }, i}$ is the predicted ASE from the first stage regression. The coefficient on ASE $\left(\beta_{3}\right)$ will thus identify the treatment effect for the group of compliers with the ASE rule. Note that because of the exogenous nature of AASE, it is not necessary to include control variables in order to estimate the local average treatment effect. However, we also conduct a robustness check in which we control for the respective temperamental dimension prior to school entrance (measured at age 4.5). Because of an

\footnotetext{
We also conducted several robustness checks to address this concern. In particular, we ran a placebo regression of ASE on the temperamental outcomes before school entrance (at age 4.5). None of the ASE coefficients were significant in this regression (detailed results are available upon request from the authors).

${ }^{5}$ We have also tried an alternative specification where we use an indicator variable for being born after the cutoff date as the regressor. All the presented results are robust if we proceed this way. This is essentially a version of the evidence from Table 2 below.
} 
oversampling of children with initial birth risks in our data (cf. Section 3), we additionally present regression results in which we restrict the sample to children with low initial risk in order to check the representativeness of our results.

We also conduct further robustness checks. We present OLS regression results that use the panel dimension of the data in order to reduce the endogeneity bias in estimating the ASE effect. In other words, we regress temperamental outcomes on observed age at school entry and all observed measures for child temperament and IQ at age 4.5. These regressions additionally include the interaction effect of ASE and indicator variables for delayed or early school entry. Thus, we allow the ASE effect to be differentiated for children who enter school according to the official ASE rule and the selective groups of children who are either retained or enter a year earlier.

\section{Data and Measures}

The sample consists of children from the Mannheim Study of Children at Risk (MARS), which follows children at varying levels of risk for unfavorable development from birth to adolescence (Laucht et al., 1997, 2004). Infants were recruited from two obstetric and six children's hospitals in the Rhine-Neckar region of Germany. Children with severe physical handicaps, obvious genetic defects or metabolic diseases were excluded. Only first-born children from singleton births to German-speaking parents, born between February 1986 and February 1988, were enrolled in the study.

To separate the independent and combined effects of organic and psychosocial risks on child development, children were selected according to combinations of different risk factors. Infants were rated according to the degree of "organic” risk, as determined by the degree of pre-, peri- or neonatal complications, and the degree of "psychosocial” risk. ${ }^{6}$ The

\footnotetext{
${ }^{6}$ Psychosocial risk is determined according to a risk index proposed by Rutter and Quinton (1977), which measures the presence of eleven adverse family characteristics (for example, marital discord or low-skilled parents). Each risk factor was scaled as either no risk, moderate risk or high risk, resulting in a 3x3 design. All
} 
sample was examined at the ages of 3 months, 2, 4.5, 8 and 11 years. After excluding children with missing values for at least one of the variables used in our empirical analysis, 360 children (173 boys, 187 girls), or 94 percent of the 382 infants in the initial wave, remained at age $11 .^{7}$ The implications of the oversampling of children with initial organic or psychosocial risks will be addressed in a robustness check in Section 4.

Temperamental outcomes of the children are measured at the ages of 4.5, 8 and 11 years. Temperament is classified according to the nine temperamental dimensions proposed by Thomas and Chess (1977). The measures are based on standardized parent interviews and structured direct observations by trained judges in four standardized settings on two different days in familiar (home visit, psychological assessment) and unfamiliar surroundings (neurological examination, EEG recording). This assessment procedure allows multiple observations and the inclusion of parental as well as expert ratings. A mean score was formed out of all five ratings (parent interview and behavioral observations) for each dimension except for rhythmicity, which solely is based on parental judgment. ${ }^{8}$

The measured dimensions are as follows (cf. Table 1 for a summary). (1) "Activity" refers to the intensity and frequency of motor behavior and ranges from being slow and inactive to being restless and overactive. In our further analysis, we also consider an indicator variable for being hyperactive which refers to a level of ability of 3.5 or higher. (2) The scale "Approach vs. Withdrawal" refers to the initial reaction to new stimuli (for instance related to unfamiliar persons or environments). Higher values imply a higher tendency to withdrawal. (3) "Soothability" refers to the ease of child's soothing after unpleasant events (for instance physical pain, disappointments or failures). The scale ranges from very difficult to easy and is

groups are about equal in size with a slight oversampling in the high-risk combinations. Sex is distributed evenly in all subgroups.

${ }^{7}$ The results presented in this paper are robust if we include children with missing observation in the regressions that do not require the respective (missing) information.

${ }^{8}$ At the ages of 3 months and 2 years the interrater reliability was measured in a preliminary study of 30 children each. Satisfactory interrater agreement was obtained between two raters ( $3 \mathrm{~m}$ : mean kappa $=0.68$, range $0.51-$ 0.84 ; 2 years: mean kappa $=0.82$, range $0.52-1.00$ ). 
not assessed at 11 years. (4) "Adaptability" reflects the amount of time needed to habituate to new stimuli and changes in the environment. At the age of 11 , adaptability also covers aspects of manageability. The scale ranges from very slow to very quickly adapting. (5) "Emotionality" refers to the general tendency of the child's mood on a continuum between positive and negative mood. (6) "Persistence" reflects the ability to continue a particular activity and to overcome corresponding obstacles. The variable ranges from very low to very high persistence. (7) "Intensitiy of reaction" refers to the vehemence of the child's expression of emotions and ranges from apathetic to irritable. (8) "Rhythmicity" represents the regularity of biological functions (e.g. sleep-wake-cycle, hunger) including, at the age of 11 , the regularity of habits. The scale ranges from unpredictable to totally regular. (9) The "threshold of responsiveness" refers to the sensitivity in the child's reaction to environmental changes or external stimuli or (such as pain, parental frowning, food temperature or new food). This variable ranges from being oversensitive to being insensitive.

Table 2 shows the means and standard deviations of these temperamental measures for the children who have already entered school (observed at age 8 and age 11). We also show these numbers separately for children born from January to June and children born between July and December. According to the school entry rule, children born between January and June are assigned a relatively younger ASE: They enter school in the year they turn six, while children born later in the year enter in the year they turn seven. The comparison of the means in both samples suggests that the outcomes "persistence," "adaptability" (at age 11) and "hyperactivity" are somewhat more favorable in the sample of potential late school entrants. We will look at a version of such "reduced form estimates" in more detail in Section 4.

\section{ASE Effects on Child Temperament}

Table 3 presents the regression results for child temperament. The first set of columns shows the direct effect of having a one-year-older AASE because of date of birth (i.e. the "cut-off date effect”). The second set of columns presents the causal impact of entering school a year 
older (i.e. the "ASE effect”). This estimate stems from the instrumental variable regression where observed ASE is instrumented by AASE. All outcome variables are standardized to zscores for ease of interpretation.

For children entering school relatively older because of a birthday late in the year (higher ASE), we find more favorable outcomes with respect to several temperamental dimensions. These children are less active and less often hyperactive (age 8), more adaptive to changes (at age 11) and more persistent (at age 8 and 11). The reduced form estimates suggest that at age 11, children also react more intensely and have a higher threshold of responsiveness. However, these effects are only significant at the five percent level of significance and not statistically significant when calculated based on the instrumental variable estimation.

According to the instrumental variable (IV) estimate, entering school one year older significantly decreases activity about 0.93 standard deviations at age 8 . This implies that the younger students are more often hyperactive: Entering school a year older decreases the probability of being at the top of the distribution measure by about 41 percentage points. At age 11, the point estimates still suggest that the younger school entrants are more often hyperactive. However, the estimated coefficients are smaller and no longer statistically different from zero. Entering school a year older because of one's date of birth also increases persistence by approximately 1.06 standard deviations at age 8 . At age 11 , the point estimate is similar in size (1.19 standard deviations). Also, while there is no significant ASE effect on adaptability to change at age 8 , there is a significant effect of 1.10 standard deviations at age 11. Note that this effect is measured after children have just entered Germany's segregated secondary-school tracks. At this age, the capability to adjust to new situations is especially important. 
The reduced form and instrumental variable estimates suggest that there are no significant ASE effects on withdrawal, soothability (only observed at age 8) and rhythmicity. In addition, the ASE effect on our measure for cognitive skills (IQ) is always statistically insignificant.

Furthermore, we conducted several robustness checks in order to challenge the validity of our estimates. One critique with respect to the AASE instrument is that date (or season) of birth might directly influence the outcomes of interest. To check this, we estimated placebo regressions where we regressed the respective temperamental outcomes before entering school (at age 4.5) on AASE. If there were seasonality in the outcomes, one would expect to observe this seasonality prior to school entrance. However, seasonal effects were not evident. All of the coefficients of our placebo regressions are statistically insignificant. ${ }^{9}$ Because there is no seasonality before school entrance, we see no reason other than age at school entry as to why season of birth affects outcomes after school entry. We also include the respective temperamental dimension as a control variable in the estimation of the ASE effects. Table 4 demonstrates that the estimated coefficients on ASE are very robust if we use this specification. The major difference is that based on the second specification, the negative ASE effect on intensity of reaction at age 11 turns statistically significant at the five percent level of significance. The respective estimate suggests that children who enter school older react about 0.92 standard deviations less intensively at age $11 .^{10}$

A further issue to be addressed is that the estimated effects might be driven by the group of children with initial birth risk who are oversampled in our data set. Therefore, we conducted a robustness check in which we only included children with low initial organic or psychosocial birth risk in the estimation sample. The respective results are presented in Table

\footnotetext{
${ }^{9}$ These insignificant results are not shown but available upon request from the corresponding author.

${ }^{10}$ It is interesting to note that ASE therefore affects some of the temperamental dimension that are associated with "difficult" children in the meaning of Thomas \& Chess, 1977. According to Thomas and Chess (1977) difficult children are characterized by negative emotionality, unstable rhythmicity, more withdrawal from new situations with highly intense reactions, and slow adaptation to changes.
} 
5. Interestingly, the significant effects tend to be even higher in absolute size in the sample of children with low initial risk. Additionally, if we restrict the sample only to children with high initial organic or psychosocial risks, all the coefficients turn insignificant (not shown here). While part of this change might be due to the small sample size, this is some evidence that the ASE effects are actually more pronounced in children with low initial risks. Overall, our finding of significant ASE effects does not seem to be driven by the oversampling of children at risk.

What conclusions for educational policy should be drawn from the finding that the age of school entry exerts significant effects on children's temperamental outcomes? One might tentatively conclude that children born before the cut-off date should be held back in order to make them the oldest in the following year's class. However, our results do not really support this conclusion, for we know nothing about the relevant counterfactual situation, i.e. how children currently complying with the age rule would perform if they enrolled later. However, we can approximate the effects of later enrollment by examining what actually happens to the children who do not comply with the school entry rule. In the MARS data about $10 \%$ of the children enter school later than they should. These students are likely to be a "negative selection" in the sense that such children are typically held back because parents or educators do not consider them to be mature enough. ${ }^{11}$ The first column of Table 6 presents regression results for the temperamental outcomes at age 8 where we control for a binary variable indicating whether the child is retained as well as the respective temperamental outcome at age 4.5 (before entering school). We also present a specification where we jointly control for all temperamental outcomes at age 4.5 (column 2 in Table 6). Even if the number of observations of retained students is rather small (36 students) many of the coefficients are significant. The results suggest that late entrants do not benefit from being retained: They

\footnotetext{
${ }^{11}$ In our data, coefficients from an estimated linear probability model suggest that children who are less persistent at age 4.5 are significantly more often retained.
} 
perform less favorable with respect to most of the observed temperamental dimensions and IQ at age eight when controlling for temperament before entering school. The findings are less pronounced if we look at the temperamental outcomes at age 11 (columns 3 and 4 of Table 6). However, there are still significant worse outcomes for the retained children with respect to adaptability, persistence and IQ.

A further check along this line is provided in Table 7: Here we separately regress the different child outcomes (at age 8 and 11, respectively) on indicator variables for early or late school entry together with observed age at school entry and the interaction variables of age at school entry and the indicator variables. All regressions draw on the panel information of the data and control for child temperament at age $4.5 .^{12}$ The pattern suggested by these results is as follows: Again, for students who follow the official ASE rule, the results point to a positive and significant ASE effect on persistence at age 11 (column 1 of Table 7). The coefficients are not statistically significant for the other outcomes. For children who entered school a year later than they should (retained entry at about age 7 or even older), we observe a lower degree of adaptability to change at age 8 and the negative effect is more pronounced for students with a higher ASE (cf. columns 2 and 3). At age 11, the retained entrants are significantly less persistent compared to regular entrants and again this effect is more pronounced for a relatively higher ASE. For very early school entrants who entered a year younger than AASE (about age 5), we observe that they tend to have a higher threshold of responsiveness at age 8 . The youngest among them also tend to be more withdrawn at age 11 (cf. columns 4 and 5).

Note that other than the instrumental variable estimates, these regressions do not reflect a causal analysis: We assume that controlling for child temperament at age 4.5 reduces (but not necessarily eliminates) the bias in estimating ASE effects. ${ }^{13}$ Therefore, we do not

\footnotetext{
${ }^{12}$ We control for the respective temperamental dimension at age 4.5. The point estimates are robust but less significant if we control for all temperamental dimensions at age 4.5.

${ }^{13}$ We assume that there are unobserved characteristics that influence both the choice of school entry age and later child development.
} 
interpret the absolute size of the effects in Table 7 . However, the presented pattern again points to the interpretation that delaying school entry for one year might not be an advantage for these children with respect to some of the temperamental dimensions.

\section{Conclusions}

In this paper we demonstrate that age of school entry has significant effects on some dimensions of child temperament. Our results imply that entering school at a relative young age (in relation to age-based cut-off dates for school entry) might harm non-cognitive skill development in children. ${ }^{14}$ We do not find significant impacts of ASE on IQ as a measure for cognitive skills. At age 11, we observe that the children who entered school relatively young behave significantly less persistent and are rated as being less adaptive to changes. This might be especially harmful because at that age, German children typically have just entered the segregated secondary-school track which is a completely new educational environment compared to primary school. Both persistence and adaptability are important traits for coping with the requirements of the upper secondary school track (Guerin et al., 1994).

Parents may wonder whether it is beneficial to retain children from entering school at a young age. Retaining children for a year makes them the oldest within the class once they enter school. This could be an advantage that fosters their further development. We have also examined the performance of children who are actually retained. These children are a selected sample, since parents will more often retain children with some kind of developmental problems. At least in this group of (selected) students, we do not find that retention is beneficial. Actually, we provide evidence that children who have been retained (and are thus more than a year older than the youngest regular school entrants) also have relatively poor temperamental outcomes when observed at age 8 and age 11. Simply entering school a year older does not seem to help children from this group. It is not clear that this effect can be generalized to the group of regular school entrants (i.e. those who comply with the official

\footnotetext{
${ }^{14}$ An alternative view is that relatively older children benefit from late school entrance due to their date of birth.
} 
entry-age rule) who suffer from being relatively young within the class if they are born before the cut-off date for school entry. However, we assume that the results provide some evidence that simply making children enter at an older age does not confer benefits. Other policy measures are needed in order to specifically assist children who are disadvantaged because of their relative age. One effective policy action might be to distribute children into separate school classes according to their relative age so that there are in more age-homogeneous groups. However, further evaluation of such a policy measure would be needed in order to assess its potential effectiveness. 


\section{References}

Bedard, K. and E. Dhuey (2006): The Persistence of Early Childhood Maturity: International Evidence of Long-Run Age Effects, Quarterly Journal of Economics, 121, 14371472.

Black, S.E., P.J. Devereux and K.G. Salvanes (2008): Too Young to Leave the Nest? The Effects of School Starting Age, NBER Working Paper 13969.

Buss, A. H., and R. Plomin (1975): A Temperament Theory of Personality Development. New York: Wiley-Interscience.

Cunha, F., J.J. Heckman, and L. Lochner (2006): Interpreting the Evidence on Life Cycle Skill Formation, in: E. Hanushek and F. Welch (eds.), Handbook of the Economics of Education, Amsterdam: North Holland.

Dhuey, E. and S. Lipscomb (2008): What Makes a Leader? Relative Age and High School Leadership, Economics of Education Review, 27, 173-183.

Dickert-Conlin, S. and T. Elder (2010): Suburban Legend: School Cutoff Dates and the Timing of Births, Economics of Education Review, 29, 826-841.

Evans, W, M.S. Morrill and S. Parente (2010): Measuring Inappropriate Medical Diagnosis and Treatment in Survey Data: The Case of ADHD among School-Age Children, Journal of Health Economics, 29, 657-673.

Fredriksson, P. and B. Öckert (2005): Is Early Learning Really More Productive? The Effect of School Starting Age on School and Labor Market Performance, IZA Discussion Papers 1659.

Guerin, D. W., A.W. Gottfried, P.H. Oliver, C.W. Thomas (1994): Temperament and School Functioning during Early Adolescence, The Journal of Early Adolescence, 14, 200225.

Mühlenweg, A. (2010), Young and Innocent: International Evidence on Age Effects Within Grades on Victimization in Elementary School, Economics Letters, 109, 157-160.

Mühlenweg, A. and P. Puhani (2010), The Evolution of the School Entry Age Effect in a School Tracking System, Journal of Human Resources, 45, 407-438.

Rothbart M.K. and J.E. Bates (1998): Temperament, in: W. Damon (series ed.) and N. Eisenberg (volume ed.), Handbook of Child Psychology: Vol. 3, Social, Emotional, and Personality Development, New York: Wiley.

Rutter, M. and D. Quinton (1977): Psychiatric Disorder - Ecological Factors and Concepts of Causation, in: M. McGurk (ed.), Ecological Factors in Human Development, Amsterdam: North Holland.

Thomas, A. and S. Chess (1977): Temperament and Development, New York: Brunner/Mazel. 
Tables and Figures

Table 1: Short explanation of observed measures of child temperament

\begin{tabular}{|c|c|c|}
\hline Temperament Factor & Explanation & Range \\
\hline Activity $^{A}$ & $\begin{array}{l}\text { Intensity and frequency of motor } \\
\text { behavior }\end{array}$ & $\begin{array}{l}\text { Ranging from inactivity and slow } \\
\text { (1) to overactive and restless (5) }\end{array}$ \\
\hline $\begin{array}{l}\text { Approach / } \\
\text { Withdrawal }\end{array}$ & $\begin{array}{l}\text { Initial reaction to new stimuli (e.g. } \\
\text { unfamiliar persons or } \\
\text { environments) }\end{array}$ & $\begin{array}{l}\text { Ranging from approach (1) to } \\
\text { withdrawal (5) }\end{array}$ \\
\hline Soothability & $\begin{array}{l}\text { Ease of child's soothing after } \\
\text { unpleasant events (physical pain, } \\
\text { disappointments or failures) }\end{array}$ & $\begin{array}{l}\text { Ranging from very difficult (1) to } \\
\text { easy / immediate soothability (5) }\end{array}$ \\
\hline Adaptability & $\begin{array}{l}\text { Amount of time needed to } \\
\text { habituate to changes in the } \\
\text { environment and new stimuli (also } \\
\text { including aspects of manageability } \\
\text { at the age of 11) }\end{array}$ & $\begin{array}{l}\text { Ranging from very slow / not at all } \\
\text { adapting (1) to very quickly } \\
\text { adapting (5) }\end{array}$ \\
\hline Emotionality & Prevailing mood & $\begin{array}{l}\text { Ranging from positive (1) to } \\
\text { negative mood (5) }\end{array}$ \\
\hline $\begin{array}{l}\text { Attention span / } \\
\text { Persistence }\end{array}$ & $\begin{array}{l}\text { Ability to continue a particular } \\
\text { activity and to overcome } \\
\text { corresponding obstacles }\end{array}$ & $\begin{array}{l}\text { Ranging from very low (1) to very } \\
\text { high persistence }(5)\end{array}$ \\
\hline Intensity of reaction & $\begin{array}{l}\text { Vehemence of the child's } \\
\text { expression of positive and } \\
\text { negative emotions }\end{array}$ & $\begin{array}{l}\text { Ranging from apathetic (1) to } \\
\text { irritable/boisterous (5) }\end{array}$ \\
\hline Rhythmicity & $\begin{array}{l}\text { Regularity of biological functions } \\
\text { (e.g. sleep-wake-cycle, hunger, } \\
\text { also including regularity of habits } \\
\text { at the age of 11) }\end{array}$ & $\begin{array}{l}\text { Ranging from unpredictable (1) to } \\
\text { totally regular (“like clockwork”) } \\
\text { (5) }\end{array}$ \\
\hline $\begin{array}{l}\text { Threshold of } \\
\text { responsiveness }\end{array}$ & $\begin{array}{l}\text { Sensitivity in the child's reaction to } \\
\text { environmental changes or external } \\
\text { stimuli (e.g. pain, parental } \\
\text { frowning, food temperature or new } \\
\text { food) }\end{array}$ & $\begin{array}{l}\text { Ranging from being oversensitive } \\
\text { (1) to insensitive or "thick- } \\
\text { skinned" (5) }\end{array}$ \\
\hline
\end{tabular}

Note: See Section 3 for further details. We follow the categorization by Thomas and Chess (1977). The regression analysis is based on z-scores of these measures. ${ }^{\text {A }}$ For activity, we additionally use an indicator variable for being "hyperactive," which refers to a level of activity of 3.5 or higher. 
Table 2: Descriptive statistics for observed temperamental outcomes

\begin{tabular}{|c|c|c|c|c|c|c|}
\hline & \multicolumn{3}{|c|}{ Observed at age 8} & \multicolumn{3}{|c|}{ Observed at age 11} \\
\hline & all children & $\begin{array}{l}\text { born before } \\
\text { cut-off date }\end{array}$ & $\begin{array}{c}\text { born after } \\
\text { cut-off date }\end{array}$ & all children & $\begin{array}{l}\text { born before } \\
\text { cut-off date }\end{array}$ & $\begin{array}{l}\text { born after } \\
\text { cut-off date }\end{array}$ \\
\hline Activity & $\begin{array}{c}3.22 \\
(0.46)\end{array}$ & $\begin{array}{c}3.29 \\
(0.38)\end{array}$ & $\begin{array}{c}3.18 \\
(0.50)\end{array}$ & $\begin{array}{l}3.06 \\
(0.43)\end{array}$ & $\begin{array}{c}3.08 \\
(0.45)\end{array}$ & $\begin{array}{c}3.05 \\
(0.42)\end{array}$ \\
\hline Hyperactive ${ }^{\text {A }}$ & $\begin{array}{c}0.27 \\
(0.44)\end{array}$ & $\begin{array}{c}0.32 \\
(0.47)\end{array}$ & $\begin{array}{c}0.23 \\
(0.42)\end{array}$ & $\begin{array}{c}0.14 \\
(0.35)\end{array}$ & $\begin{array}{c}0.18 \\
(0.38)\end{array}$ & $\begin{array}{c}0.12 \\
(0.33)\end{array}$ \\
\hline Withdrawal & $\begin{array}{c}3.44 \\
(0.59)\end{array}$ & $\begin{array}{c}3.47 \\
(0.57)\end{array}$ & $\begin{array}{c}3.42 \\
(0.60)\end{array}$ & $\begin{array}{c}3.38 \\
(0.56)\end{array}$ & $\begin{array}{c}3.38 \\
(0.54)\end{array}$ & $\begin{array}{c}3.38 \\
(0.58)\end{array}$ \\
\hline Soothability & $\begin{array}{c}3.85 \\
(0.65)\end{array}$ & $\begin{array}{l}3.80 \\
(0.64)\end{array}$ & $\begin{array}{c}3.88 \\
(0.66)\end{array}$ & --- & --- & --- \\
\hline Adaptability & $\begin{array}{c}3.86 \\
(0.60)\end{array}$ & $\begin{array}{c}3.88 \\
(0.57)\end{array}$ & $\begin{array}{c}3.85 \\
(0.62)\end{array}$ & $\begin{array}{c}4.07 \\
(0.52)\end{array}$ & $\begin{array}{c}3.98 \\
(0.51)\end{array}$ & $\begin{array}{c}4.13 \\
(0.51)\end{array}$ \\
\hline Emotionality & $\begin{array}{c}3.38 \\
(0.59)\end{array}$ & $\begin{array}{c}3.40 \\
(0.54)\end{array}$ & $\begin{array}{c}3.37 \\
(0.63)\end{array}$ & $\begin{array}{c}3.17 \\
(0.55)\end{array}$ & $\begin{array}{c}3.16 \\
(0.56)\end{array}$ & $\begin{array}{c}3.17 \\
(0.55)\end{array}$ \\
\hline $\begin{array}{l}\text { Attention span / } \\
\text { Persistence }\end{array}$ & $\begin{array}{c}3.80 \\
(0.75)\end{array}$ & $\begin{array}{c}3.68 \\
(0.74)\end{array}$ & $\begin{array}{c}3.88 \\
(0.75)\end{array}$ & $\begin{array}{c}3.90 \\
(0.70)\end{array}$ & $\begin{array}{c}3.79 \\
(0.68)\end{array}$ & $\begin{array}{c}3.96 \\
(0.70)\end{array}$ \\
\hline $\begin{array}{l}\text { Intensity of } \\
\text { reaction }\end{array}$ & $\begin{array}{c}3.18 \\
(0.41)\end{array}$ & $\begin{array}{c}3.18 \\
(0.36)\end{array}$ & $\begin{array}{c}3.17 \\
(0.45)\end{array}$ & $\begin{array}{c}3.09 \\
(0.44)\end{array}$ & $\begin{array}{c}3.15 \\
(0.46)\end{array}$ & $\begin{array}{c}3.05 \\
(0.43)\end{array}$ \\
\hline Rhythmicity & $\begin{array}{c}3.70 \\
(0.80)\end{array}$ & $\begin{array}{c}3.73 \\
(0.85)\end{array}$ & $\begin{array}{c}3.68 \\
(0.76)\end{array}$ & $\begin{array}{c}3.86 \\
(0.69)\end{array}$ & $\begin{array}{c}3.86 \\
(0.66)\end{array}$ & $\begin{array}{c}3.86 \\
(0.72)\end{array}$ \\
\hline $\begin{array}{l}\text { Threshold of } \\
\text { responsiveness }\end{array}$ & $\begin{array}{c}3.28 \\
(0.39)\end{array}$ & $\begin{array}{c}3.29 \\
(0.41)\end{array}$ & $\begin{array}{c}3.27 \\
(0.37)\end{array}$ & $\begin{array}{c}3.22 \\
(0.36)\end{array}$ & $\begin{array}{c}3.26 \\
(0.39)\end{array}$ & $\begin{array}{c}3.19 \\
(0.33)\end{array}$ \\
\hline Intelligence (IQ) & $\begin{array}{c}98.31 \\
(18.55) \\
\end{array}$ & $\begin{array}{c}98.81 \\
(20.18) \\
\end{array}$ & $\begin{array}{c}97.99 \\
(17.45) \\
\end{array}$ & $\begin{array}{c}99.72 \\
(19.85) \\
\end{array}$ & $\begin{array}{l}100.08 \\
(21.51)\end{array}$ & $\begin{array}{c}99.49 \\
(18.73) \\
\end{array}$ \\
\hline $\begin{array}{l}\text { Number of } \\
\text { observations }\end{array}$ & 360 & 142 & 218 & 360 & 142 & 218 \\
\hline
\end{tabular}


Table 3: Cut-off date and age effect on measures of child temperament

\begin{tabular}{|c|c|c|c|c|}
\hline & \multicolumn{2}{|c|}{$\begin{array}{l}\text { 1: Cut-off date } \\
\text { effect (RF) }\end{array}$} & \multicolumn{2}{|c|}{$\begin{array}{l}\text { 2: ASE effect } \\
\text { (IV) }\end{array}$} \\
\hline & Age 8 & Age 11 & Age 8 & Age 11 \\
\hline Activity & $\begin{array}{c}-0.36^{* *} \\
(0.16)\end{array}$ & $\begin{array}{l}-0.13 \\
(0.18)\end{array}$ & $\begin{array}{l}-0.93^{*} \\
(0.50)\end{array}$ & $\begin{array}{l}-0.35 \\
(0.47)\end{array}$ \\
\hline Hyperactive & $\begin{array}{c}-0.16^{* *} \\
(0.08)\end{array}$ & $\begin{array}{l}-0.08 \\
(0.06)\end{array}$ & $\begin{array}{l}-0.41^{*} \\
(0.23)\end{array}$ & $\begin{array}{l}-0.20 \\
(0.17)\end{array}$ \\
\hline Withdrawal & $\begin{array}{l}-0.06 \\
(0.16)\end{array}$ & $\begin{array}{c}0.02 \\
(0.16)\end{array}$ & $\begin{array}{l}-0.15 \\
(0.43)\end{array}$ & $\begin{array}{c}0.06 \\
(0.42)\end{array}$ \\
\hline Soothability & $\begin{array}{c}0.20 \\
(0.18)\end{array}$ & -- & $\begin{array}{c}0.53 \\
(0.51)\end{array}$ & -- \\
\hline Adaptability & $\begin{array}{c}0.08 \\
(0.16)\end{array}$ & $\begin{array}{c}0.42 * * \\
(0.18)\end{array}$ & $\begin{array}{c}0.21 \\
(0.44)\end{array}$ & $\begin{array}{l}1.10^{* *} \\
(0.55)\end{array}$ \\
\hline Emotionality & $\begin{array}{c}0.03 \\
(0.17)\end{array}$ & $\begin{array}{c}0.06 \\
(0.16)\end{array}$ & $\begin{array}{c}0.07 \\
(0.44)\end{array}$ & $\begin{array}{c}0.15 \\
(0.43)\end{array}$ \\
\hline Attention span / Persistence & $\begin{array}{c}0.41^{* *} \\
(0.18)\end{array}$ & $\begin{array}{l}0.46^{* *} \\
(0.18)\end{array}$ & $\begin{array}{l}1.06^{*} \\
(0.58)\end{array}$ & $\begin{array}{l}1.19 * * \\
(0.54)\end{array}$ \\
\hline Intensity of reaction & $\begin{array}{l}-0.02 \\
(0.17)\end{array}$ & $\begin{array}{l}-0.30 * \\
(0.18)\end{array}$ & $\begin{array}{l}-0.06 \\
(0.44)\end{array}$ & $\begin{array}{l}-0.77 \\
(0.50)\end{array}$ \\
\hline Rhythmicity & $\begin{array}{l}-0.08 \\
(0.18)\end{array}$ & $\begin{array}{c}0.02 \\
(0.17)\end{array}$ & $\begin{array}{l}-0.21 \\
(0.46)\end{array}$ & $\begin{array}{c}0.04 \\
(0.45)\end{array}$ \\
\hline Threshold of responsiveness & $\begin{array}{l}-0.18 \\
(0.18)\end{array}$ & $\begin{array}{l}-0.31^{*} \\
(0.18)\end{array}$ & $\begin{array}{l}-0.48 \\
(0.48)\end{array}$ & $\begin{array}{l}-0.81 \\
(0.51)\end{array}$ \\
\hline Intelligence & $\begin{array}{c}0.00 \\
(0.18)\end{array}$ & $\begin{array}{c}0.08 \\
(0.19)\end{array}$ & $\begin{array}{c}0.00 \\
(0.47)\end{array}$ & $\begin{array}{c}0.21 \\
(0.50)\end{array}$ \\
\hline Observations & 360 & 360 & 360 & 360 \\
\hline
\end{tabular}


Table 4: Cut-off date and age effect on measures of child temperament, controlling for the respective temperament before school entry (measured at age 4.5)

\begin{tabular}{|c|c|c|c|c|}
\hline & \multicolumn{2}{|c|}{$\begin{array}{c}\text { 1: Cut-off date } \\
\text { effect (RF) }\end{array}$} & \multicolumn{2}{|c|}{$\begin{array}{c}\text { 2: ASE effect } \\
\text { (IV) }\end{array}$} \\
\hline & Age 8 & Age 11 & Age 8 & Age 11 \\
\hline Activity & $\begin{array}{c}-0.38 * * \\
(0.15)\end{array}$ & $\begin{array}{l}-0.15 \\
(0.17)\end{array}$ & $\begin{array}{c}-0.98^{* *} \\
(0.47)\end{array}$ & $\begin{array}{l}-0.39 \\
(0.45)\end{array}$ \\
\hline Hyperactive & $\begin{array}{c}-0.16^{* *} \\
(0.07)\end{array}$ & $\begin{array}{l}-0.08 \\
(0.06)\end{array}$ & $\begin{array}{l}-0.42 * \\
(0.22)\end{array}$ & $\begin{array}{l}-0.21 \\
(0.17)\end{array}$ \\
\hline Withdrawal & $\begin{array}{l}-0.02 \\
(0.15)\end{array}$ & $\begin{array}{c}0.04 \\
(0.16)\end{array}$ & $\begin{array}{l}-0.06 \\
(0.39)\end{array}$ & $\begin{array}{c}0.11 \\
(0.41)\end{array}$ \\
\hline Soothability & $\begin{array}{c}0.16 \\
(0.16)\end{array}$ & --- & $\begin{array}{c}0.41 \\
(0.44)\end{array}$ & --- \\
\hline Adaptability & $\begin{array}{c}0.10 \\
(0.15)\end{array}$ & $\begin{array}{c}0.43^{* *} \\
(0.17)\end{array}$ & $\begin{array}{c}0.25 \\
(0.39)\end{array}$ & $\begin{array}{l}1.13 * * \\
(0.53)\end{array}$ \\
\hline Emotionality & $\begin{array}{c}0.06 \\
(0.16)\end{array}$ & $\begin{array}{c}0.09 \\
(0.16)\end{array}$ & $\begin{array}{c}0.17 \\
(0.42)\end{array}$ & $\begin{array}{c}0.23 \\
(0.43)\end{array}$ \\
\hline Attention span / Persistence & $\begin{array}{l}0.25^{*} \\
(0.14)\end{array}$ & $\begin{array}{l}0.33^{* *} \\
(0.15)\end{array}$ & $\begin{array}{l}0.63^{*} \\
(0.39)\end{array}$ & $\begin{array}{l}0.81 * * \\
(0.40)\end{array}$ \\
\hline Intensity of reaction & $\begin{array}{l}-0.10 \\
(0.15)\end{array}$ & $\begin{array}{c}-0.35^{* *} \\
(0.17)\end{array}$ & $\begin{array}{l}-0.27 \\
(0.41)\end{array}$ & $\begin{array}{l}-0.92 * \\
(0.50)\end{array}$ \\
\hline Rhythmicity & $\begin{array}{l}-0.07 \\
(0.17)\end{array}$ & $\begin{array}{c}0.02 \\
(0.17)\end{array}$ & $\begin{array}{l}-0.17 \\
(0.43)\end{array}$ & $\begin{array}{c}0.06 \\
(0.45)\end{array}$ \\
\hline Threshold of responsiveness & $\begin{array}{c}-0.21 \\
(0.17)\end{array}$ & $\begin{array}{c}-0.33^{* *} \\
(0.17) \\
\end{array}$ & $\begin{array}{l}-0.54 \\
(0.47)\end{array}$ & $\begin{array}{l}-0.86^{*} \\
(0.51) \\
\end{array}$ \\
\hline Intelligence & $\begin{array}{c}-0.14 \\
(0.12)\end{array}$ & $\begin{array}{l}-0.05 \\
(0.13)\end{array}$ & $\begin{array}{l}-0.34 \\
(0.29) \\
\end{array}$ & $\begin{array}{l}-0.13 \\
(0.32)\end{array}$ \\
\hline Observations & 360 & 360 & 360 & 360 \\
\hline
\end{tabular}

Note: $\mathrm{RF}=$ reduced form estimate, IV = instrumental variable estimate. ${ }^{*}$ Significant at least at the ten percent level. ${ }^{* *}$ Significant at least at the five percent level. 
Table 5: "Low-risk sample": Cut-off date and age effect on measures of child temperament (no controls included)

\begin{tabular}{|c|c|c|c|c|}
\hline & \multicolumn{2}{|c|}{$\begin{array}{l}\text { 1: Cut-off date } \\
\text { effect (RF) }\end{array}$} & \multicolumn{2}{|c|}{$\begin{array}{l}\text { 2: ASE effect } \\
\text { (IV) }\end{array}$} \\
\hline & Age 8 & Age 11 & Age 8 & Age 11 \\
\hline Activity & $\begin{array}{c}-0.28 \\
(0.19)\end{array}$ & $\begin{array}{c}-0.20 \\
(0.24)\end{array}$ & $\begin{array}{c}-0.65 \\
(0.50)\end{array}$ & $\begin{array}{c}-0.46 \\
(0.58)\end{array}$ \\
\hline Hyperactive & $\begin{array}{c}-0.24 * * \\
(0.11)\end{array}$ & $\begin{array}{l}-0.10 \\
(0.09)\end{array}$ & $\begin{array}{l}-0.54 * \\
(0.29)\end{array}$ & $\begin{array}{l}-0.23 \\
(0.22)\end{array}$ \\
\hline Withdrawal & $\begin{array}{l}-0.07 \\
(0.24)\end{array}$ & $\begin{array}{c}0.08 \\
(0.22)\end{array}$ & $\begin{array}{c}-0.16 \\
(0.56)\end{array}$ & $\begin{array}{c}0.18 \\
(0.51)\end{array}$ \\
\hline Soothability & $\begin{array}{l}0.43 * \\
(0.23)\end{array}$ & --- & $\begin{array}{c}0.97 \\
(0.61)\end{array}$ & --- \\
\hline Adaptability & $\begin{array}{c}0.20 \\
(0.24)\end{array}$ & $\begin{array}{c}0.67 * * \\
(0.21)\end{array}$ & $\begin{array}{c}0.46 \\
(0.56)\end{array}$ & $\begin{array}{c}1.53^{* *} \\
(0.66)\end{array}$ \\
\hline Emotionality & $\begin{array}{c}0.25 \\
(0.24)\end{array}$ & $\begin{array}{c}0.27 \\
(0.22)\end{array}$ & $\begin{array}{c}0.57 \\
(0.56)\end{array}$ & $\begin{array}{c}0.62 \\
(0.53)\end{array}$ \\
\hline Attention span / Persistence & $\begin{array}{c}0.42^{* *} \\
(0.20)\end{array}$ & $\begin{array}{c}0.58^{* *} \\
(0.20)\end{array}$ & $\begin{array}{l}0.96^{*} \\
(0.56)\end{array}$ & $\begin{array}{l}1.32 * * \\
(0.60)\end{array}$ \\
\hline Intensity of reaction & $\begin{array}{l}-0.07 \\
(0.20)\end{array}$ & $\begin{array}{l}-0.47^{*} \\
(0.24)\end{array}$ & $\begin{array}{c}-0.16 \\
(0.45)\end{array}$ & $\begin{array}{c}-1.01 * \\
(0.62)\end{array}$ \\
\hline Rhythmicity & $\begin{array}{c}0.06 \\
(0.27)\end{array}$ & $\begin{array}{c}0.10 \\
(0.25)\end{array}$ & $\begin{array}{c}0.14 \\
(0.62)\end{array}$ & $\begin{array}{c}0.22 \\
(0.58)\end{array}$ \\
\hline Threshold of responsiveness & $\begin{array}{l}-0.15 \\
(0.26)\end{array}$ & $\begin{array}{c}-0.33 \\
(0.24)\end{array}$ & $\begin{array}{c}-0.33 \\
(0.61)\end{array}$ & $\begin{array}{c}-0.76 \\
(0.63)\end{array}$ \\
\hline Intelligence & $\begin{array}{c}0.07 \\
(0.20)\end{array}$ & $\begin{array}{c}0.12 \\
(0.19)\end{array}$ & $\begin{array}{c}0.16 \\
(0.46)\end{array}$ & $\begin{array}{c}0.28 \\
(0.46)\end{array}$ \\
\hline
\end{tabular}

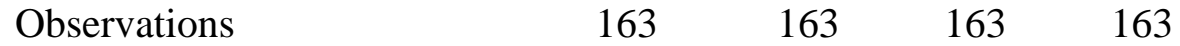

Note: $\mathrm{RF}=$ reduced form estimate, IV = instrumental variable estimate. $*$ Significant at least at the ten percent level. $* *$ Significant at least at the five percent level. 
Table 6: Temperamental outcomes of retained children (OLS regressions)

\begin{tabular}{|c|c|c|c|c|}
\hline & \multicolumn{2}{|c|}{ Age 8} & \multicolumn{2}{|c|}{ Age 11} \\
\hline & $\begin{array}{l}\text { Controlling } \\
\text { for given } \\
\text { characteristic } \\
\text { at age } 4.5\end{array}$ & $\begin{array}{c}\text { Controlling } \\
\text { for all } \\
\text { temperamental } \\
\text { dimensions at } \\
\text { age } 4.5\end{array}$ & $\begin{array}{l}\text { Controlling } \\
\text { for given } \\
\text { characteristic } \\
\text { at age } 4.5\end{array}$ & $\begin{array}{c}\text { Controlling } \\
\text { for all } \\
\text { temperamental } \\
\text { dimensions at } \\
\text { age } 4.5\end{array}$ \\
\hline Activity & $\begin{array}{l}0.39 * * \\
(0.16)\end{array}$ & $\begin{array}{l}0.27 * \\
(0.16)\end{array}$ & $\begin{array}{c}0.23 \\
(0.16)\end{array}$ & $\begin{array}{c}0.19 \\
(0.17)\end{array}$ \\
\hline Hyperactive & $\begin{array}{l}0.22 * * \\
(0.07)\end{array}$ & $\begin{array}{l}0.13^{*} \\
(0.07)\end{array}$ & $\begin{array}{c}0.08 \\
(0.06)\end{array}$ & $\begin{array}{c}0.01 \\
(0.06)\end{array}$ \\
\hline Withdrawal & $\begin{array}{l}-0.25 \\
(0.16)\end{array}$ & $\begin{array}{l}-0.27^{*} \\
(0.16)\end{array}$ & $\begin{array}{l}-0.07 \\
(0.17)\end{array}$ & $\begin{array}{l}-0.07 \\
(0.18)\end{array}$ \\
\hline Soothability & $\begin{array}{c}-0.68^{* *} \\
(0.15)\end{array}$ & $\begin{array}{c}-0.47^{* *} \\
(0.15)\end{array}$ & --- & --- \\
\hline Adaptability & $\begin{array}{c}-0.46^{* *} \\
(0.15)\end{array}$ & $\begin{array}{l}-0.30^{*} \\
(0.16)\end{array}$ & $\begin{array}{c}-0.69 * * \\
(0.17)\end{array}$ & $\begin{array}{c}-0.38^{* *} \\
(0.16)\end{array}$ \\
\hline Emotionality & $\begin{array}{c}-0.22 \\
(0.16)\end{array}$ & $\begin{array}{l}-0.19 \\
(0.17)\end{array}$ & $\begin{array}{l}-0.07 \\
(0.17)\end{array}$ & $\begin{array}{l}-0.05 \\
(0.18)\end{array}$ \\
\hline Attention span / Persistence & $\begin{array}{c}-0.61^{* *} \\
(0.14)\end{array}$ & $\begin{array}{c}-0.57^{* *} \\
(0.14)\end{array}$ & $\begin{array}{c}-0.33^{* *} \\
(0.15)\end{array}$ & $\begin{array}{l}-0.28 * \\
(0.15)\end{array}$ \\
\hline Intensity of reaction & $\begin{array}{c}0.26 \\
(0.16)\end{array}$ & $\begin{array}{c}0.16 \\
(0.16)\end{array}$ & $\begin{array}{c}0.23 \\
(0.17)\end{array}$ & $\begin{array}{c}0.16 \\
(0.17)\end{array}$ \\
\hline Rhythmicity & $\begin{array}{l}-0.21 \\
(0.17)\end{array}$ & $\begin{array}{l}-0.08 \\
(0.17)\end{array}$ & $\begin{array}{l}-0.24 \\
(0.17)\end{array}$ & $\begin{array}{l}-0.03 \\
(0.18)\end{array}$ \\
\hline Threshold of responsiveness & $\begin{array}{c}0.19 \\
(0.17)\end{array}$ & $\begin{array}{c}0.36 * * \\
(0.18)\end{array}$ & $\begin{array}{c}0.18 \\
(0.17)\end{array}$ & $\begin{array}{l}0.30^{*} \\
(0.18)\end{array}$ \\
\hline Intelligence & $\begin{array}{c}-0.28^{* *} \\
(0.12)\end{array}$ & $\begin{array}{c}-0.63^{* *} \\
(0.15)\end{array}$ & $\begin{array}{c}-0.44^{* *} \\
(0.13)\end{array}$ & $\begin{array}{c}-0.81^{* *} \\
(0.16)\end{array}$ \\
\hline Observations & 360 & 360 & 360 & 360 \\
\hline
\end{tabular}

Note: Results from separate OLS regressions of the temperamental outcomes on an indicator variable for retained school entrance and temperament before school entrance. * Significant at least at the ten percent level. ** Significant at least at the five percent level. 
Table 7: Age effects (OLS) controlling for the respective child temperament at age 4.5

\begin{tabular}{|c|c|c|c|c|c|}
\hline & Entry age & $\begin{array}{c}\text { Retained } \\
\text { entry }\end{array}$ & $\begin{array}{c}\text { Entry age * } \\
\text { retained entry }\end{array}$ & Early entry & $\begin{array}{l}\text { Entry age * } \\
\text { early entry }\end{array}$ \\
\hline & \multicolumn{5}{|c|}{ Age 8} \\
\hline Activity & $\begin{array}{l}-0.19 \\
(0.18)\end{array}$ & $\begin{array}{c}7.55 \\
(5.02)\end{array}$ & $\begin{array}{l}-0.96 \\
(0.69)\end{array}$ & $\begin{array}{c}0.03 \\
(5.26)\end{array}$ & $\begin{array}{l}-0.05 \\
(0.88)\end{array}$ \\
\hline Hyperactive & $\begin{array}{l}-0.08 \\
(0.08)\end{array}$ & $\begin{array}{c}0.99 \\
(2.32)\end{array}$ & $\begin{array}{l}-0.10 \\
(0.32)\end{array}$ & $\begin{array}{l}-0.60 \\
(2.44)\end{array}$ & $\begin{array}{c}0.08 \\
(0.41)\end{array}$ \\
\hline Withdrawal & $\begin{array}{l}-0.06 \\
(0.18)\end{array}$ & $\begin{array}{c}3.03 \\
(5.08)\end{array}$ & $\begin{array}{l}-0.44 \\
(0.69)\end{array}$ & $\begin{array}{l}-0.65 \\
(5.34)\end{array}$ & $\begin{array}{c}0.07 \\
(0.89)\end{array}$ \\
\hline Soothability & $\begin{array}{l}-0.02 \\
(0.18)\end{array}$ & $\begin{array}{c}7.65 \\
(4.89)\end{array}$ & $\begin{array}{l}-1.13^{*} \\
(0.67)\end{array}$ & $\begin{array}{c}2.03 \\
(5.16)\end{array}$ & $\begin{array}{l}-0.34 \\
(0.86)\end{array}$ \\
\hline Adaptability & $\begin{array}{c}0.02 \\
(0.18)\end{array}$ & $\begin{array}{c}12.54^{* *} \\
(4.92)\end{array}$ & $\begin{array}{c}-1.77^{* *} \\
(0.67)\end{array}$ & $\begin{array}{c}4.36 \\
(5.19)\end{array}$ & $\begin{array}{l}-0.71 \\
(0.87)\end{array}$ \\
\hline Emotionality & $\begin{array}{l}-0.06 \\
(0.19)\end{array}$ & $\begin{array}{l}-1.30 \\
(5.23)\end{array}$ & $\begin{array}{c}0.15 \\
(0.71)\end{array}$ & $\begin{array}{l}-5.87 \\
(5.51)\end{array}$ & $\begin{array}{c}0.98 \\
(0.92)\end{array}$ \\
\hline Attention span / Persistence & $\begin{array}{l}-0.01 \\
(0.15)\end{array}$ & $\begin{array}{l}-4.29 \\
(4.25)\end{array}$ & $\begin{array}{c}0.50 \\
(0.58)\end{array}$ & $\begin{array}{l}-5.91 \\
(4.48)\end{array}$ & $\begin{array}{c}0.99 \\
(0.75)\end{array}$ \\
\hline Intensity of reaction & $\begin{array}{l}-0.06 \\
(0.18)\end{array}$ & $\begin{array}{l}-0.12 \\
(5.12)\end{array}$ & $\begin{array}{c}0.06 \\
(0.70)\end{array}$ & $\begin{array}{c}3.34 \\
(5.39)\end{array}$ & $\begin{array}{l}-0.53 \\
(0.90)\end{array}$ \\
\hline Rhythmicity & $\begin{array}{l}-0.25 \\
(0.19)\end{array}$ & $\begin{array}{l}-2.96 \\
(5.30)\end{array}$ & $\begin{array}{c}0.40 \\
(0.72)\end{array}$ & $\begin{array}{c}2.66 \\
(5.61)\end{array}$ & $\begin{array}{l}-0.44 \\
(0.94)\end{array}$ \\
\hline Threshold of responsiveness & $\begin{array}{l}-0.10 \\
(0.20)\end{array}$ & $\begin{array}{l}-3.44 \\
(5.55)\end{array}$ & $\begin{array}{c}0.50 \\
(0.76) \\
\end{array}$ & $\begin{array}{l}11.36^{*} \\
(5.82)\end{array}$ & $\begin{array}{c}-1.94 * * \\
(0.97) \\
\end{array}$ \\
\hline \multirow[t]{2}{*}{ Intelligence } & $\begin{array}{l}-0.21 \\
(0.13) \\
\end{array}$ & $\begin{array}{c}2.70 \\
(3.73) \\
\end{array}$ & $\begin{array}{c}-0.39 \\
(0.51) \\
\end{array}$ & $\begin{array}{c}0.47 \\
(3.90) \\
\end{array}$ & $\begin{array}{l}-0.14 \\
(0.65)\end{array}$ \\
\hline & \multicolumn{5}{|c|}{ Age 11} \\
\hline Activity & $\begin{array}{c}0.02 \\
(0.18)\end{array}$ & $\begin{array}{c}6.14 \\
(5.18)\end{array}$ & $\begin{array}{l}-0.81 \\
(0.71)\end{array}$ & $\begin{array}{c}5.66 \\
(5.42)\end{array}$ & $\begin{array}{l}-0.96 \\
(0.91)\end{array}$ \\
\hline Hyperactive & $\begin{array}{l}-0.05 \\
(0.07)\end{array}$ & $\begin{array}{c}0.51 \\
(1.93)\end{array}$ & $\begin{array}{l}-0.06 \\
(0.26)\end{array}$ & $\begin{array}{l}-0.28 \\
(2.02)\end{array}$ & $\begin{array}{c}0.03 \\
(0.34)\end{array}$ \\
\hline Withdrawal & $\begin{array}{c}0.08 \\
(0.20)\end{array}$ & $\begin{array}{l}-2.82 \\
(5.52)\end{array}$ & $\begin{array}{c}0.37 \\
(0.75)\end{array}$ & $\begin{array}{l}9.94^{*} \\
(5.81)\end{array}$ & $\begin{array}{l}-1.67 * \\
(0.97)\end{array}$ \\
\hline Adaptability & $\begin{array}{l}0.33^{*} \\
(0.19)\end{array}$ & $\begin{array}{c}5.65 \\
(5.37)\end{array}$ & $\begin{array}{l}-0.89 \\
(0.73)\end{array}$ & $\begin{array}{c}3.53 \\
(5.66)\end{array}$ & $\begin{array}{l}-0.56 \\
(0.95)\end{array}$ \\
\hline Emotionality & $\begin{array}{c}0.08 \\
(0.20)\end{array}$ & $\begin{array}{l}-1.41 \\
(5.45)\end{array}$ & $\begin{array}{c}0.18 \\
(0.74)\end{array}$ & $\begin{array}{c}5.82 \\
(5.74)\end{array}$ & $\begin{array}{l}-0.96 \\
(0.96)\end{array}$ \\
\hline Attention span / Persistence & $\begin{array}{l}0.38^{* *} \\
(0.17)\end{array}$ & $\begin{array}{l}9.62 * * \\
(4.67)\end{array}$ & $\begin{array}{c}-1.39 * * \\
(0.64)\end{array}$ & $\begin{array}{c}3.83 \\
(4.92)\end{array}$ & $\begin{array}{l}-0.60 \\
(0.82)\end{array}$ \\
\hline Intensity of reaction & $\begin{array}{l}-0.28 \\
(0.20)\end{array}$ & $\begin{array}{c}7.40 \\
(5.44)\end{array}$ & $\begin{array}{l}-0.95 \\
(0.74)\end{array}$ & $\begin{array}{l}-1.27 \\
(5.73)\end{array}$ & $\begin{array}{c}0.18 \\
(0.96)\end{array}$ \\
\hline Rhythmicity & $\begin{array}{c}0.00 \\
(0.20)\end{array}$ & $\begin{array}{c}2.88 \\
(5.58)\end{array}$ & $\begin{array}{l}-0.42 \\
(0.76)\end{array}$ & $\begin{array}{c}6.43 \\
(5.90)\end{array}$ & $\begin{array}{l}-1.08 \\
(0.99)\end{array}$ \\
\hline Threshold of responsiveness & $\begin{array}{l}-0.16 \\
(0.20)\end{array}$ & $\begin{array}{c}6.72 \\
(5.57)\end{array}$ & $\begin{array}{l}-0.88 \\
(0.76)\end{array}$ & $\begin{array}{c}7.57 \\
(5.85)\end{array}$ & $\begin{array}{l}-1.33 \\
(0.98)\end{array}$ \\
\hline Intelligence & $\begin{array}{l}-0.20 \\
(0.14) \\
\end{array}$ & $\begin{array}{c}-2.09 \\
(3.97) \\
\end{array}$ & $\begin{array}{c}0.24 \\
(0.54) \\
\end{array}$ & $\begin{array}{c}-0.65 \\
(4.16) \\
\end{array}$ & $\begin{array}{c}0.04 \\
(0.70) \\
\end{array}$ \\
\hline
\end{tabular}

Note: Results from separate OLS regressions of the temperamental outcomes on school entry age; indicator variables for retained or early school entrance; interaction variables of entry age and the retained/early entrance indicators and temperament before school entrance.

* Significant at least at the ten percent level. ${ }^{* *}$ Significant at least at the five percent level. 